\title{
Antimicrobial Activities and Antagonists of Bacilysin and Anticapsin
}

\author{
By M. KENIG AND E. P. ABRAHAM \\ Sir William Dunn School of Pathology, University of Oxford, Oxford OXI $3 R E$ \\ (Received 5 June 1975; revised I 2 November 1975)
}

\begin{abstract}
SUMMARY
The dipeptide antibiotic bacilysin is active against a wide range of bacteria and against Candida albicans. Its C-terminal amino acid, anticapsin, is a very poor antibacterial agent. The activities of both substances are strongly dependent on the nature of the culture medium. In a minimal medium the minimum inhibitory concentration for bacilysin with $E$. coli B is $\mathrm{IO}^{-3} \mu \mathrm{g} \mathrm{ml}^{-1}$. The action of bacilysin is antagonized by a variety of dipeptides and that of anticapsin by a number of amino acids. With several bacteria, bacilysin-resistant mutants are found in unusually large numbers. It is suggested that peptide and amino acid transport systems play a role in these phenomena. The antimicrobial action of bacilysin is also inhibited by glucosamine and $\mathrm{N}$-acetylglucosamine. This antibiotic may therefore interfere with glucosamine synthesis and thus with the synthesis of microbial cell walls.
\end{abstract}

\section{INTRODUCTION}

An antibiotic produced by a strain of Bacillus subtilis was found by Abraham, Callow \& Gilliver 1946) to cause partial lysis of growing cultures of Staphylococcus aureus (NCTC657I). This substance, named bacilysin (Abraham \& Florey, 1949), was later isolated from culture filtrates of $B$. subtilis AI4 (Rogers, Newton \& Abraham, 1965; Walker \& Abraham, 1970a) and shown (Walker \& Abraham, 1970 b) to be a dipeptide with the structure I (Fig. I). The culture filtrates also contained a new amino acid (II; Fig. I), named AAI, which was identical with the C-terminal amino acid of bacilysin but did not show the antistaphylococcal activity of the latter (Walker \& Abraham 1970 b). Whitney et al. (1970) detected in the culture fluid of a strain of Streptomyces griseoplanus NRRL3507 a substance which they named anticapsin because it inhibited the formation of the hyaluronic acid capsule of group A streptococci. Anticapsin was isolated by Shah et al. (1970) and shown by Neuss et al. (I970) to have the structure II. Anticapsin was thus identical with the C-terminal amino acid of bacilysin.

This paper is concerned with the antimicrobial activities of bacilysin and anticapsin and with the action of antagonists, some of which may inhibit the transport of these antibiotics into microbial cells.

\section{METHODS}

Organisms. Staphylococcus epidermidis, Serratia marcescens and Escherichia coli type I (a rough laboratory strain) were obtained from Dr Vollum, Radcliffe Infirmary, Oxford. Escherichia coli в was obtained from Sir Paul Fildes and came originally from the Pasteur Institute, Paris. Salmonella gallinarum was from the Lilly Research Laboratories, Indianapolis, Indiana, U.S.A. Salmonella typhi (Mrs S.) was the strain described by 

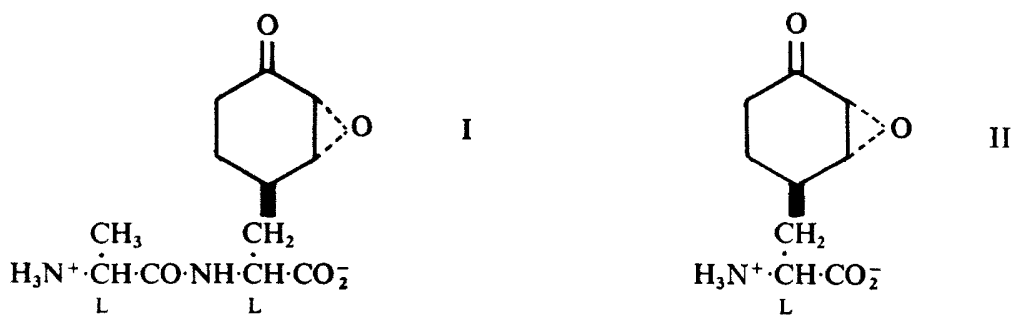

Fig. I. Structure of bacilysin, I, and amino acid AAI (anticapsin), II.

Felix \& Pitt (1935). Candida albicans was strain NCYC597. Other organisms used are described in the text.

Reagents. D-Glucosamine hydrochloride and $N$-acetyl-D-glucosamine were from $\mathrm{BDH}$; amino acids were also from $\mathrm{BDH}$, except L-leucine, L-phenylalanine, D-phenylalanine and D-methionine which were from Sigma. Dipeptides and tripeptides were from Sigma except L-alanylglycine (Koch-Light) and triglycine (BDH). Nicotinic acid and thiamine pyrophosphate chloride were from BDH and D-biotin from Sigma.

Preparation and assay of bacilysin. Bacilysin was prepared from culture filtrates of B. subtilis AI4 by the method of Walker \& Abraham (1970 a). The antibiotic was assayed by the hole-plate method (Brownlee et al., 1948) with Staphylococcus aureus (Oxford) NCTC657 I grown on Lab-Lemco agar as the test organism. The bacilysin concentration in a solution is expressed in units $/ \mathrm{ml}$; these units are the units of cephalosporin $\mathrm{C}$ sodium salt ( 8 units per $\mathrm{mg}$ ) required per $\mathrm{ml}$ to give a zone of inhibition of the same diameter. The specific activity of pure bacilysin was 250 units/mg (Walker \& Abraham, 1970a).

Determination of sensitivity of organisms. The sensitivity of organisms to bacilysin and anticapsin and the reversal of their action by antagonists was determined by the hole-plate method (Brownlee et al., 1948).

Chemically-defined media. Minimal medium contained (g/l distilled water): $\mathrm{NaNH}_{4} \mathrm{HPO}_{4}$ (microcosmic salt), $\mathrm{I} \cdot 5 ; \mathrm{KH}_{2} \mathrm{PO}_{4}, \mathrm{I} ; \mathrm{MgSO}_{4} \cdot 7 \mathrm{H}_{2} \mathrm{O}, 0 \cdot 2$; glucose, 2. For minimal agar, Oxoid No. I or No. 3 agar ( $\left.12 \mathrm{~g} \mathrm{l}^{-1}\right)$ was added. For Candida albicans the minimal medium contained biotin $\left(2.5 \mathrm{mg} \mathrm{l}^{-1}\right)$ and (unless otherwise stated) sodium glutamate $\left(\mathrm{I}^{\cdot} 5 \mathrm{~g} \mathrm{l}^{-1}\right)$ instead of microcosmic salt as the source of nitrogen.

Dulbecco agar was prepared by the addition of $100 \mathrm{ml}$ of ten times concentrated Dulbecco's minimum essential medium (Bio-cult Laboratories, Glasgow) to $900 \mathrm{ml}$ liquid $\left(\mathrm{I} \cdot 4 \%\right.$, w/v) Oxoid No. 3 agar containing $0.196 \% \mathrm{NaHCO}_{3}$ at $48{ }^{\circ} \mathrm{C}$.

Undefined media. Lab-Lemco agar was prepared from ( $\mathrm{g} / \mathrm{l}$ distilled water): Oxoid LabLemco extract, Io; peptone (Evans Medical Ltd, Speke, Liverpool), Io; NaCl, 5; Oxoid No. 3 agar, 20. The $\mathrm{pH}$ was adjusted to $6 \cdot 8$. The agar was melted, and a solution of phenol red $(0.5 \%, 5 \mathrm{ml})$ and phosphate buffer $\mathrm{pH} 6.8$ was added.

Nutrient broth was Oxoid No. 2.

Sabouraud agar contained $\left(\mathrm{g} \mathrm{l}^{-1}\right)$ : Oxoid mycological peptone, 10; glucose, 40; D-biotin, 0.0025 ; Oxoid No. 3 agar, 20. Sabouraud liquid medium was identical except that it contained no agar.

Growth in liquid media. Bacteria were grown aerobically, with shaking at $37^{\circ} \mathrm{C}$ in inverted T-tubes (Kay \& Fildes 1950). Candida albicans was grown similarly at $30^{\circ} \mathrm{C}$. The extinction of the culture was measured (after dilution if necessary) in a Spekker absorptiometer (Adam Hilger Ltd) with a neutral-grey filter $\left(\mathrm{H}_{508}\right)$ and a $\mathbf{I} \cdot 8 \mathrm{~cm}$ light path. 
Minimum inhibitory concentrations (m.i.c. values). The m.i.c. values of bacilysin and anticapsin for $E$. coli were measured by use of serial twofold dilutions of the antibiotic. The inoculum was prepared from an overnight brain-heart infusion agar slope culture by dilution in minimal medium. The mixture in minimal medium contained about $10^{5}$ to $10^{6}$ bacteria/ml, plus bacilysin at concentrations which ranged from 0.0313 to 0.000125 $\mu \mathrm{g} \mathrm{ml}^{-1}$. These tubes, together with controls, were incubated for $48 \mathrm{~h}$ at $37^{\circ} \mathrm{C}$. The lowest concentration of bacilysin which prevented visible growth was taken as the m.i.c.

The proportion of bacilysin-resistant bacteria in cultures of Staph. aureus. Dilutions of the culture were spread over the surface of Lab-Lemco agar plates with bacilysin $\left(40 \mu \mathrm{g} \mathrm{ml}^{-1}\right)$ or without it. The plates were incubated for $20 \mathrm{~h}$ at $37^{\circ} \mathrm{C}$ and the colonies counted.

\section{RESULTS}

\section{Antimicrobial activities of bacilysin and anticapsin on solid media}

On Lab-Lemco agar, bacilysin ( $300 \mu \mathrm{g} \mathrm{ml}^{-1}$ ) gave inhibition zones (often $>30 \mathrm{~mm}$ diam) against the following organisms: Staph. aureus (Oxford), Staph. epidermidis, Micrococcus tetragenus NCTC750I, Corynebacterium xerosis NCTC7243, Bacillus megatherium de Bary, Sarcina lutea NCTC8340, Salm. typhi, Salm. gallinarum, Ser. marcescens and Proteus vulgaris NCTC4636. On minimal agar $E$. coli в and $E$. coli type I were highly sensitive to bacilysin, but $B$. subtilis AI4 (by which it is produced) and Pseudomonas aeruginosa NCTC8203 were resistant.

In contrast with bacilysin, anticapsin had no detectable activity at a concentration of I $\mathrm{mg} \mathrm{ml}^{-1}$ against Staph. aureus, Salm. typhi and Salm. gallinarum, organisms which could only be grown in a relatively rich medium, but showed some activity against $E$. coli B (Table I) and $E$. coli type I, growing in minimal medium. With $E$. coli $\mathrm{B}, 2 \times 1 \mathrm{I}^{3}$ times as much anticapsin as bacilysin was required to produce a zone of the same diameter (Table I).

When tested on Sabouraud agar against $C$. albicans, bacilysin produced a large zone of inhibition (diameter $43 \mathrm{~mm}$ ) at $80 \mu \mathrm{g} \mathrm{ml}^{-1}$, but on minimal agar its activity was much higher (Table I). Anticapsin on minimal agar was about one-sixth as active as bacilysin (Table I).

In contrast to many other antibiotics, bacilysin produced zones of inhibition against several organisms which contained numerous isolated colonies. With Staph. aureus (in LabLemco agar), Salm. typhi (Lab-Lemco) and C. albicans (in Sabouraud and minimal agar), colonies which grew within zones of inhibition due to bacilysin gave cultures which were completely resistant to the same concentrations of bacilysin. Determination of the proportion of resistant bacteria in two resting-phase cultures of Staph. aureus at bacilysin concentrations of $40 \mu \mathrm{g} \mathrm{ml}^{-1}$ gave values of $\mathrm{I} \cdot 8 \times \mathrm{IO}^{-6}$ and $8.5 \times \mathrm{IO}^{-6}$. In contrast, no resistant colonies were obtained with $E$. coli в or $E$. coli type I on minimal agar with either bacilysin or anticapsin. Bacilysin-resistant colonies of $C$. albicans on minimal agar were resistant to anticapsin, and vice versa.

\section{Lysis and emergence of resistant organisms in liquid media}

Following the addition of bacilysin (final concentration $40 \mu \mathrm{g} \mathrm{ml}^{-1}$ ) to a culture of Staph. aureus or Salm. typhi the extinction of both cultures continued to increase for about ${ }^{\cdot} 5 \mathrm{~h}$ and then fell, due to lysis. A renewed increase in extinction was observed after $8 \mathrm{~h}$ for Staph. aureus and to h for Salm. typhi. The changes in extinction of Staph. aureus in the presence of bacilysin at $2.4 \mu \mathrm{g} \mathrm{ml}^{-1}(8 \cdot 9 \mu \mathrm{M})$ and $24 \mu \mathrm{g} \mathrm{ml}^{-1}(89 \mu \mathrm{M})$ are shown in Fig. 2. Similar changes were observed when bacilysin at $40 \mu \mathrm{g} \mathrm{ml}^{-1}$ was added to C. albicans growing in Sabouraud's medium, or when either bacilysin (I $\mu \mathrm{g} \mathrm{ml}^{-1}$ ) or anticapsin (10 $\mu \mathrm{g} \mathrm{ml}^{-1}$ ) was added to this organism growing in minimal medium. On reaching the stationary phase the cultures 
Table 1. Activity of bacilysin and anticapsin against $E$. coli $\mathrm{B}$ and C. albicans NCYC597 on minimal agar

Escherichia coli zones of inhibition were measured after incubation at $37^{\circ} \mathrm{C}$ overnight; C. albicans incubation was at $28^{\circ} \mathrm{C}$ for $48 \mathrm{~h}$.

\begin{tabular}{|c|c|c|c|c|}
\hline & \multicolumn{2}{|c|}{ Concentration } & \multicolumn{2}{|c|}{ Diameter of inhibition zone (mm) } \\
\hline & $\mu \mathrm{g} \mathrm{ml}^{-1}$ & $\mu_{\mathrm{M}}$ & E. coli & C. albicans \\
\hline \multirow[t]{5}{*}{ Bacilysin } & $1 \cdot 0$ & 3.7 & & 45 \\
\hline & 0.5 & I.85 & & 38 \\
\hline & 0.25 & 0.92 & 24 & 32 \\
\hline & 0.125 & 0.46 & 19 & 26 \\
\hline & 0.062 & 0.23 & 16 & \\
\hline \multirow[t]{7}{*}{ Anticapsin } & 500 & 2500 & 28 & \\
\hline & 250 & 1250 & 23 & \\
\hline & 125 & 625 & 16 & \\
\hline & 4 & 20 & & 46 \\
\hline & 2 & 10 & & 37 \\
\hline & I & 5 & & 28 \\
\hline & 0.5 & $2 \cdot 5$ & & 23 \\
\hline
\end{tabular}

consisted largely, if not entirely, of bacilysin-resistant organisms when tested by the holeplate method.

In contrast, the partial lysis of a culture of $E$. coli B which occurred in minimal medium after the addition of bacilysin was not followed by observable growth during more than $24 \mathrm{~h}$ (Fig. 2). Hence, m.i.c. values could be determined in liquid culture. After $48 \mathrm{~h}$ the m.i.c. values for bacilysin were 0.008 and $0.00 \mathrm{I} \mu \mathrm{g} \mathrm{ml}^{-1}$ with inocula of $8 \times 10^{5}$ and $8 \times 10^{4}$ bacilli/ml respectively. Minimum inhibitory concentrations for anticapsin were 250 and $62 \mu \mathrm{g} \mathrm{ml}^{-1}$ with inocula of $7 \times 10^{5}$ and $7 \times 10^{4} \mathrm{bacilli} / \mathrm{ml}$ respectively.

\section{Antagonists of the action of bacilysin and anticapsin}

Peptides. Bacilysin appeared to be at least five times as active against Staph. aureus NCTC657I on Dulbecco agar as on Lab-Lemco agar. Since the Dulbecco medium contains free amino acids but no peptides, it seemed possible that the presence of peptides in the LabLemco medium was responsible for the lower activity of the dipeptide bacilysin in the latter.

A number of dipeptides inhibited, to different degrees, the activity of bacilysin against Staph. aureus on Dulbecco agar and E. coli в on minimal agar (Table 2). When E. coli в was grown in the presence of $3.7 \mu \mathrm{M}$-bacilysin and the concentration of $\mathrm{L}$-alanyl-L-phenylalanine was increased stepwise from $0 \cdot 125$ to $4 \mathrm{~mm}$, inhibition was first detected when the molar ratio of the dipeptide to bacilysin was about 50:I and approached completion when it was about 150:I. L-Alanyl-L-phenylalanine also inhibited the action of anticapsin ( $5 \mathrm{~mm})$ against $E$. coli $\mathrm{B}$, although here the maximum inhibition observed (with 4 mM-dipeptide) was $57 \%$. In a concentration of I $5 \mathrm{~mm}$ it completely inhibited the activity of both bacilysin $(0.37 \mu \mathrm{M})$ and anticapsin (125 $\mu \mathrm{M})$ against $C$. albicans.

Amino acids. In contrast to the results obtained with dipeptides, none of $17 \mathrm{~L}$-amino acids ( $5 \mathrm{mM}$ ) caused a substantial reduction in the activity of bacilysin $(7 \cdot 4 \mu \mathrm{M})$ against $E$. coli $\mathrm{B}$ (Table 3), but more than half caused a major decrease in the activity of anticapsin ( $5 \mathrm{mM}$ ). The three D-amino acids were much less effective as antagonists than were the corresponding L-forms. In minimal glutamate medium, L-phenylalanine ( $15 \mathrm{~mm}$ ) eliminated the action of anticapsin (I $25 \mu \mathrm{M})$ against $C$. albicans, but had no effect on the action of bacilysin $(0.37 \mu \mathrm{M})$. 


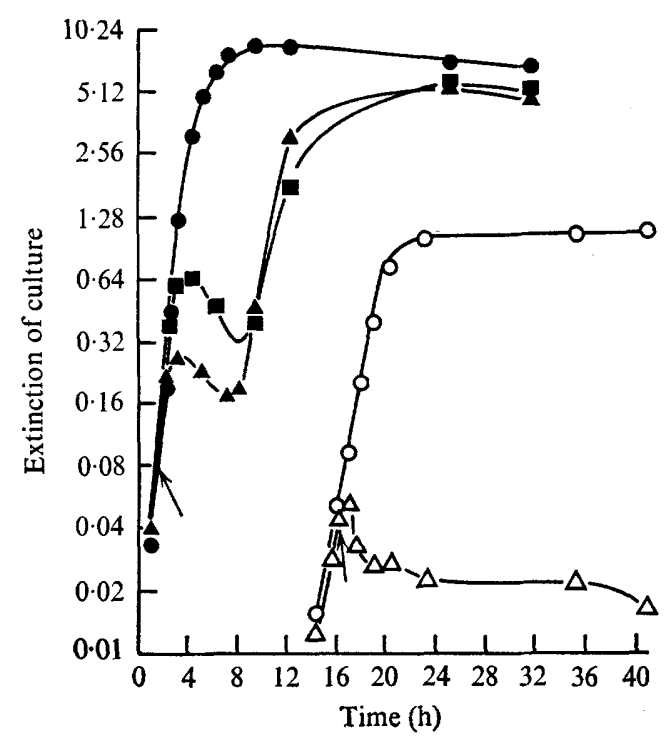

Fig. 2

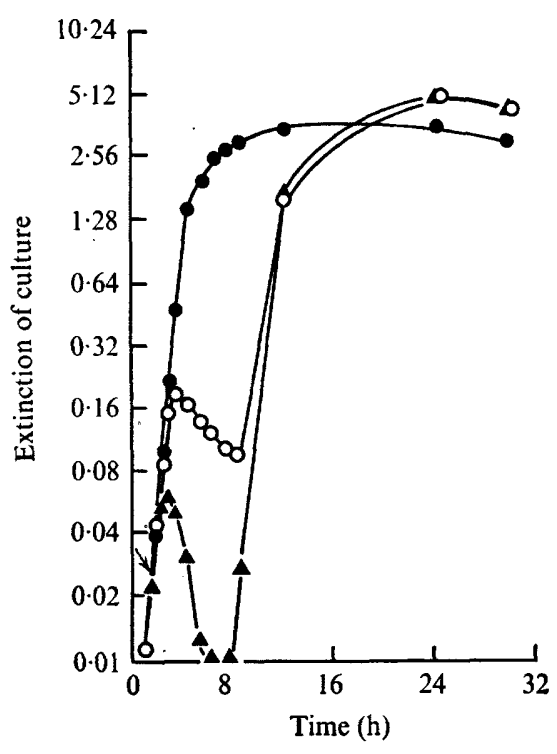

Fig. 3

Fig. 2. Effect of bacilysin on growing cultures of Staph. aureus NCTC657I in nutrient broth and of $E$. coli B in minimal medium at $37^{\circ} \mathrm{C}$. Bacilysin was added at the points indicated by the arrows. - Control culture of Staph. aureus; $\mathbf{D}$, Staph. aureus with $8.9 \mu \mathrm{M}$-bacilysin; $\boldsymbol{\Delta}$, Staph. aureus with $89 \mu \mathrm{M}$-bacilysin; $O$, control culture of $E$. coli; $\triangle, E$. coli with $74 \mu \mathrm{M}$-bacilysin.

Fig. 3. Inhibition by glucosamine of the effect of bacilysin on Staph. aureus NCTC657I in nutrient broth at $37^{\circ} \mathrm{C}$. Bacilysin (final concentration $8 \mathrm{I} \mu \mathrm{M}$ ) and glucosamine were added at the time indicated by the arrow., $400 \mu \mathrm{M}$-glucosamine; $\mathrm{O}, 100 \mu \mathrm{M}$-glucosamine; $\boldsymbol{\Lambda}$, $10 \mu \mathrm{M}$-glucosamine.

\section{Table 2.Reversal of the action of bacilysin against Staph. aureus and E. coli by peptides}

Dulbecco agar plates were seeded with Staph. aureus NCTC657I and minimal agar plates with $E$. coli B. For determination of activities against Staph. aureus the concentration of bacilysin was $29.6 \mu \mathrm{M}$ and that of each peptide was $6 \mathrm{mM}$. With $E$. coli $\mathrm{B}$ the corresponding concentrations were $3.7 \mu_{\mathrm{M}}$ and $\mathrm{I} \mathrm{mM}$. Zone diameters were read after incubation overnight at $37^{\circ} \mathrm{C}$ and compared with those produced by standard solutions of bacilysin alone.

Decrease in bacilysin activity $(\%)$ in

\section{Peptide}

L-Alanyl-L-phenylalanine

L-Alanylglycine

L-Alanyl-L-alanine

L-Alanyl-L-serine

L-Alanyl-L-methionine

L-Alanyl-L-leucine

Glycylglycine

Glycyl-L-leucine

L-Leucyl-L-phenylalanine

L-Phenylalanyl-L-alanine

L-Alanyl-L-tyrosine

L-Tyrosyl-L-tyrosine

Triglycine

Tri-L-phenylalanine the presence of peptide against:

\begin{tabular}{cc}
\hline Staph. aureus & E. coli \\
$>75$ & $>91$ \\
49 & $>93$ \\
$>73$ & $>95$ \\
36 & 89 \\
$>75$ & 91 \\
$>75$ & $>93$ \\
$<14$ & 82 \\
66 & $>93$ \\
$>73$ & $>94$ \\
41 & $>94$ \\
71 & \\
60 & \\
14 & 29 \\
& 65
\end{tabular}




\title{
Table 3. Reversal of the action of bacilysin and anticapsin against $E$. coli by L- and D-amino acids
}

\begin{abstract}
Activities were determined by the hole-plate method on minimal agar plates seeded with $E$. coli B. The solutions tested contained bacilysin alone, anticapsin alone, the amino acid alone, and mixtures of bacilysin $(7.4 \mu \mathrm{M})$ or anticapsin $(5 \mathrm{~mm})$ with each of the amino acids. The amino acid concentration was $5 \mathrm{mM}$, except that of L-cystine which was $2.5 \mathrm{~mm}$.
\end{abstract}

$\quad$ Amino acid
L-Alanine
D-Alanine
L-Arginine- $\mathrm{HCl}$
L-Aspartic acid
L-Cystine
L-Sodium glutamate
Glycine
L-Histidine- $\mathrm{HCl} . \mathrm{H}_{2} \mathrm{O}$
L-Leucine
L-Isoleucine
L-Lysine- $\mathrm{HCl}$
L-Methionine
D-Methionine
L-Phenylalanine
D-Phenylalanine
L-Proline
L-Serine
L-Threonine
L-Tryptophan
L-Valine

\begin{tabular}{|c|c|}
\hline \multicolumn{2}{|c|}{ Decrease in activity $(\%)$} \\
\hline Bacilysin & Anticapsin \\
\hline$<16$ & $\begin{array}{l}43 \\
24\end{array}$ \\
\hline$<16$ & $<14$ \\
\hline 16 & $<\mathrm{I} 4$ \\
\hline$<16$ & 14 \\
\hline 16 & 34 \\
\hline I 6 & 24 \\
\hline$<16$ & $<\mathrm{I} 4$ \\
\hline$<$ I6 & 89 \\
\hline$<$ I6 & 84 \\
\hline$<16$ & $<\mathrm{I} 4$ \\
\hline$<16$ & 87 \\
\hline & 12 \\
\hline I6 & 87 \\
\hline & 14 \\
\hline$<\mathrm{I} 6$ & 14 \\
\hline$<16$ & 62 \\
\hline$<16$ & 86 \\
\hline$<\mathrm{I} 6$ & $<\mathrm{I} 4$ \\
\hline$<16$ & $8 \mathrm{I}$ \\
\hline
\end{tabular}

Ammonium ions. When sodium glutamate replaced $\mathrm{NaNH}_{4} \mathrm{HPO}_{4}$ as the nitrogen source for the growth of $C$. albicans in minimal agar, the inhibition zones produced by bacilysin $\left(0.2 \mu \mathrm{g} \mathrm{ml}^{-1}\right)$ and anticapsin $\left(50 \mu \mathrm{g} \mathrm{ml}^{-1}\right)$ increased in diameter from 25 to $35 \mathrm{~mm}$ and from 35 to $4 \mathrm{I} \mathrm{mm}$, respectively.

Glucosamine and $N$-acetylglucosamine. When bacilysin $(8 \mathrm{I} \mu \mathrm{M})$ and glucosamine $(400 \mu \mathrm{M})$ were added together to a culture of Staph. aureus, no lysis was observed and, after growth had come to an end, the culture was still bacilysin-sensitive; with I00 $\mu \mathrm{M}$ - and I0 $\mu \mathrm{M}$ glucosamine there was partial lysis and the final cultures were bacilysin-resistant (Fig. 3). Addition of glucosamine ( $\mathrm{I} \cdot \mathrm{O} \mathrm{mM}) 2 \mathrm{~h}$ after bacilysin $(8 \mathrm{I} \mu \mathrm{M})$, when lysis had already begun, was followed by further lysis and then by growth to give a culture containing a higher proportion of bacilysin-resistant organisms than the original culture.

The activity of bacilysin against Staph. aureus, Salm. typhi, and C. albicans on Lab-Lemco agar was reduced by more than $95 \%$ by the incorporation of glucosamine ( $4.6 \mathrm{~mm}$ ) into the agar. The presence of $0.5 \mu \mathrm{M}-N$-acetylglucosamine in minimal agar caused a decrease in bacilysin activity against $E$. coli $\mathrm{B}$ of about $65 \%$.

Glucosamine and $\mathrm{N}$-acetylglucosamine produced zones of growth on Lab-Lemco and minimal agar plates seeded with Staph. aureus or E. coli type I and containing bacilysin in inhibitory concentrations. The diameters of such zones indicated that $N$-acetylglucosamine was about twice as effective as glucosamine in reversing the action of bacilysin against Staph. aureus, and more than 1000 times as effective as glucosamine in reversing it against $E$. coli type I. $N$-acetylglucosamine was also much more effective than glucosamine in reversing the action of anticapsin in minimal agar seeded with $E$. coli $\mathbf{B}$. 


\section{DISCUSSION}

Bacilysin is active against a wide range of bacteria and against $C$. albicans, but its activity is strongly dependent on the composition of the culture medium. Against $E$. coli $\mathrm{B}$ in a minimal medium its activity is very high (m.i.c. $10^{-3} \mu \mathrm{g} \mathrm{ml}^{-1}$ ). Anticapsin is a poor antibacterial agent, but shows detectable activity against $E$. coli and $C$. albicans in simple media. It is inactive against organisms which require a relatively rich medium for growth.

The findings that a variety of dipeptides and amino acids antagonize the action of bacilysin and anticapsin raise the question whether the antagonism is due to a competition for transport systems. In $E$. coli there appear to be separate transport systems for dipeptides and oligopeptides (Payne \& Gilvarg, 1968; Barak \& Gilvarg, 1975) and for amino acids and peptides (Cohen \& Rickenberg, 1956). Some amino acids appear to share an uptake system of rather broad specificity, and it is of interest that there is a similarity between the ability of certain monoamino monocarboxylic acids to inhibit the action of anticapsin (Table 3) against $E$. coli $\mathrm{B}$ and to inhibit the uptake of $\left[{ }^{14} \mathrm{C}\right]$ homoserine and $\left[{ }^{14} \mathrm{C}\right]$ threonine by this organism (Templeton \& Savageau, 1974). The fact that anticapsin shows a higher activity against $C$. albicans in a medium containing glutamate than it does in one containing ammonium ions as a source of nitrogen is consistent with reports that ammonium ions inhibit the uptake of amino acids by fungi (Grenson, Hou \& Crabeel, 1970; Hunter \& Segal, 1973; Robinson, Anthony \& Drabble, I973). Inhibition of the action of anticapsin, as well as of bacilysin, against $E$. coli and $C$. albicans by L-alanyl-L-phenylalanine raises the question whether the dipeptide can use an amino acid transport system in these organisms. Magill et al. (1973) found that histidylglycine inhibited the uptake of histidine by Neurospora crassa.

Bacilysin has a much higher activity than anticapsin against $E$. coli in a medium containing only ammonium ions as a source of nitrogen, suggesting that the dipeptide, bacilysin, is transported into the organism more efficiently than its C-terminal amino acid, anticapsin. Peptides may be taken up more readily than their constituent amino acids (for references see Barak \& Gilvarg, 1975).

Analogy with other studies of peptide transport and peptide-resistant organisms suggests that bacilysin-resistant strains of Staph. aureus, Salm. typhi and C. albicans may arise by mutations in genes concerned with peptide transport. De Felice et al. (1973) observed that triornithine-resistant colonies of $E$. coli were defective in their oligopeptide transport system. Barak \& Gilvarg (I974) concluded that the frequency of mutation at the locus in $E$. coli for the genes concerned with oligopeptide transport is approximately roo times higher than the normal frequency of mutation. A possible explanation of the failure to obtain bacilysin-resistant mutants of $E$. coli may lie in the ability of dipeptides to use the oligopeptide transport system of this organism (Payne, 1968).

Inhibition of the action of bacilysin against Staph. aureus by glucosamine does not appear to be due to interference with bacilysin transport (Kenig, Vandamme \& Abraham, 1976) and, in conjunction with the fact that anticapsin inhibits the glucosamine synthetase of Strep. pyogenes and the formation of its hyaluronic acid capsule (Whitney \& Funderburk, 1970), raises the possibility that the antimicrobial activity of bacilysin is a consequence of a failure in glucosamine synthesis. The finding that $\mathrm{N}$-acetylglucosamine is somewhat more effective than glucosamine as a bacilysin antagonist with Staph. aureus as the test organism and very much more effective with $E$. coli, may reflect differences in the uptake of these two substances by the bacteria concerned (Dobrogosz, I968; Suzuki et al., 1972).

Walton \& Rickes (1962) showed that the antibacterial activity of bacillin, an antibiotic of unknown structure produced by $B$. subtilis (Foster \& Woodruff, 1946), was reversed by 
$\mathrm{N}$-acetylglucosamine. Recent work has indicated that bacilysin, a dipeptide antibiotic tetaine, and bacillin are identical (Kaminski \& Sokolowska, I973; Atsumi, Oiwa \& Omura, 1975).

We are indebted to the Science Research Council and the Medical Research Council for financial support and to the Lilly Research Laboratories, Indianapolis, Indiana, U.S.A. for a gift of anticapsin.

\section{REFERENCES}

Abraham, E. P., Callow, D. \& Gilliver, K. (1946). Adaptation of Staphylococcus aureus to growth in the presence of certain antibiotics. Nature, London 158, 818-82 I.

Abraham, E. P. \& Florey, H. W. (1949). Antibiotics from bacteria in the genus Bacillus. In Antibiotics, vol. 1, p. 457 . Edited by H. W. Florey, E. Chain, N. G. Heatley, M. A. Jennings, A. G. Sanders, E. P. Abraham and M. E. Florey. Oxford: Oxford University Press.

Atsum, K., Oiwa, R. \& OmURA, S. (1975). Production of bacillin by Bacillus subtilis sp. strain no. KM-208 and its identity with tetaine (bacilysin). Journal of Antibiotics 28, 77-78.

Barak, Z. \& Gilvarg, C. (1974). Triornithine-resistant strain of Escherichia coli: isolation, definition and genetic studies. Journal of Biological Chemistry 249, I43-148.

Barak, Z. \& Gilvarg, C. (1975). Peptide transport. In Biomembranes, vol. 7, pp. 167-218. Edited by L. A. Manson. London: Plenum Press.

Brownlee, K. A., Delves, C. S., Dorman, M., Green, C. A., Grenfell, E., Johnson, J. D. A. \& Smith, N. (1948). The biological assay of streptomycin by a modified cylinder plate method. Journal of General Microbiology 2, 40-53.

Cohen, G. N. \& Rickenberg, H. V. (1956). Concentration specifique reversible des amino acides chez Escherichia coli. Annales de l'Institut Pasteur 91, 693-720.

De Felice, M., Guardiola, J., Lamberti, A. \& IacCarino, M. (I973). Escherichia coli K-I 2 mutants altered in the transport systems for oligo- and dipeptides. Journal of Bacteriology $116,751-756$.

Dorrogosz, W. J. (1968). $N$-Acetylglucosamine assimilation in Escherichia coli and its relation to catabolite repression. Journal of Bacteriology 95, 585-59I.

Felix, A. \& Pitr, R. M. (1935). Virulence and immunogenic activities of B. typhosus in relation to its antigenic constituents. Journal of Hygiene 35, 428-436.

Foster, J. W. \& WoOdRUFF, H. B. (1946). Bacillin, a new antibiotic substance from a soil isolate of Bacillus subtilis. Journal of Bacteriology 51, 363-369.

Grenson, M., Hou, C. \& Crabeel, M. (1970). Multiplicity of the amino acid permeases in Saccharomyces cerevisiae. Journal of Bacteriology 103, 770-777.

Hunter, D. R. \& Segal, I. H. (1973). Effect of weak acids on amino acid transport by Penicillium chrysogenum. Journal of Bacteriology $113,1184-1192$.

Kaminski, K. \& Sokolowska, T. (1973). The probable identity of bacilysin and tetaine. Journal of Antibiotics 26, $184-185$.

KAY, D. \& Fildes, P. (1950). The calcium requirement of a typhoid bacteriophage. British Journal of Experimental Pathology 31, 338-348.

Kenig, M., Vandamme, E. \& Abraham, E. P. (1976). The mode of action of bacilysin and anticapsin and biochemical properties of bacilysin-resistant mutants. Journal of General Microbiology 94, 46-54.

Magill, C. W., Nelson, S. O., D’Ambrosio, S. M. \& Glover, G. I. (1973). Histidine uptake in mutant strains of Neurospora crassa via the general transport system for amino acids. Journal of Bacteriology I13, 1320-I325.

Neuss, N., Molloy, B. B., Shah, R., \& De la Higuera, N. (1970). The structure of anticapsin, a new biologically active metabolite of Streptomyces griseoplanus. Biochemical Journal 118, 57I-575.

PAYNE, J. W. (1968). Oligopeptide transport in Escherichia coli. Journal of Biological Chemistry 243, 33953403.

PAyne, J. W. \& Gilvarg, C. (1968). The role of terminal carboxyl group in peptide transport in Escherichia coli. Journal of Biological Chemistry 243, 335-340.

Robinson, J. H., Anthony, C. \& Drabble, W. T. (I973). Regulation of the acidic amino-acid permease of Aspergillus nidulans. Journal of General Microbiology 79, 65-80.

Rogers, H. J., Newron, G. G. F. \& Abraham, E. P. (1965). Production and purification of bacilysin. Biochemical Journal 97, 573-578.

Shah, R., Neuss, N., Gorman, M. \& BoECK, L. D. (1970). Isolation, purification and characterisation of anticapsin. Journal of Antibiotics 23, 613-617.

Suzuki, J., Hori, M., SAeki, T. \& Umezawa, H. (I972). Macarbomycin, an inhibitor of peptidoglycan synthesis. Journal of Antibiotics 25, 94-104.

Templeton, B. A. \& Sayageau, M. A. (1974). Transport of biosynthetic intermediates. Journal of Bacterio$\log y$ 117, 1002-1009. 
WALKER, J. E. \& ABRAHAM, E. P. (I970a). Isolation of bacilysin and a new amino acid from culture filtrates of Bacillus subtilis. Biochemical Journal 118, 557-56r.

WALKER, J. E. \& ABRAhAM, E. P. (1970 b). The structure of bacilysin and other products of Bacillus subtilis. Biochemical Journal 118, 563-570.

WaLton, R. B. \& RiCKES, E. L. (1962). Reversal of the antibiotic, bacillin, by $N$-acetylglucosamine. Journal of Bacteriology 84, I I48-I I5I.

WHITNEY, J. G. \& FUNDERBURK, S. S. (1970). Anticapsin, a new biologically active metabolite. IV. Mechanism of action. Abstracts for the X International Congress for Microbiology, Mexico City, p. IOI.

Whitney, J. G., Funderburk, S. S., Westhead, J. E., Lively, D. H., Solengurg, J. M. \& DenNey, J. W. (1970). Anticapsin, a new biologically active metabolite. I. Anticapsular screen and assay. Bacteriological Proceedings, 7. 